\title{
SOSIALISASI DAN PENDAMPINGAN \\ PAKET TEKNOLOGI HAYATI UNTUK BUDIDAYA CABE DI KAWASAN PESISIR BENGKULU
}

\section{SOCIALIZATION AND ACCOMPANIMENT OF BIOLOGICAL TECHNOLOGY FOR RED CHILLI AT COASTAL AREA OF BENGKULU}

\author{
Oleh: \\ Yudhy Harini Bertham, Abimanyu Dipo Nusantara, Sukisno \\ Program Studi Ilmu Tanah Jurusan Budidaya Pertanian \\ Fakultas Pertanian Universitas Bengkulu \\ Email: yudhyhb@gmail.com
}

\begin{abstract}
Pepper plants that grow in coastal areas facing a multiple stress i.e high temperatures, strong winds, drought, salinity, and nutrient deficiencies. Cultivation of plants in coastal areas requires specific technology, but cheap and environmentally friendly. Socialization, training, and mentoring implemented to improve the ability of farmers to implement the cultivation of high yielded chillies in coastal areas. The methods implemented namely (1) socialization potential of coastal land for plant cultivation and the technology needed, (2) training production of biocompost and arbuscular mycorrhizal fungi inoculant, and (3) demoplot pepper cultivation in coastal lands. The activities carried out in the Desa Pekik Nyaring and Beringin Raya, Central Bengkulu Regency, Bengkulu province. Demoplot arranged Split-split plot with a randomized block design Complete two-factor with the location, genotype chili and fertilizer as the main plot, subplot, and sub-sub plot. The results show that farmers can absorb the information and training well to produce biocompost and arbuscular mycorrhizal fungi inculant. Desa Beringin Raya is more potential for pepper cultivation compared Desa Pekik Nyaring. Better technology need to be formulated to pepper cultivation in that village.
\end{abstract}

Keywords: pepper, mycorhiza, organic, coastal area

\section{PENDAHULUAN}

Kabupaten Bengkulu Tengah merupakan salah satu wilayah integral dari Provinsi Bengkulu. Kabupaten tersebutdihuni oleh 104.797 jiwa dengan luasan areal 1.223,94 km² yang tersebar pada 10 kecamatan yaitu Talang Empat, Karang Tinggi, Taba Penanjung, Merigi Kelindang, Pagar Jati, Merigi Sakti, Pondok Kelapa, Pondok Kubang, Pematang Tiga dan Bang Haji. Kecamatan Pondok Kelapa merupakan kawasan dengan jumlah penduduk terbanyak.

Kabupaten Bengkulu Tengah di sebelah utara berbatasan dengan Kabupaten Bengkulu Utara, di sebelah timur dengan Kabupaten Kepahiang, di sebelah Selatan dengan Kabupaten Seluma, dan di sebelah barat dibatasi oleh Samudra Indonesia dan Kabupaten 
Bengkulu Utara.Sebagian besar wilayahnya berupa daratan dengan elevasi 0 - $150 \mathrm{~m}$ dari permukaan laut (dpl) dan sebagian lainnyayang terletak di sebelah timur merupakan areal berbukit-bukit dengan elevasi $541 \mathrm{~m}$ (dpl). Jenis tanah pada umumnya adalah Organosol, Alluvial, Regosol, Podsolik Merah Kuning, Latosol, Andosol, dan asosiasi beberapa jenis tanah (BPS Bengkulu Tengah, 2012). Luasan terbesarnya sebesar 368.41 Ha atau 30\% didominasi oleh tanah Regosol atau Entisol dan sebagian besar diantaranya merupakan kawasan pesisir laut yang pada umumnya ditumbuhi semak belukar dan tidak dijadikan sebagai lahan budidaya tanaman oleh penduduk.

Lahan pesisir umumnya merupakan tanah dengan tekstur pasir, tanpa struktur, berkadar garam tinggi namun berkadar hara dan bahan organik rendah. Oleh sebab itu lahan di kawasan pesisir dapat dikatakan tidak dapat memberikan kontribusi pendapatan dari sektor pertanian bagi penghuninya. Fakta menunjukkan bahwa kawasan pesisir dapat dengan sentuhan teknologi yang tepat dapat dimanfaatkan untuk kesejahteraan masyarakat penghuninya. Sebagai contoh, budidaya sayuran tekah berhasil dilaksanakan di kawasan pesisir Kabupaten Kulon Progo.Secara sporadis masyarakat pesisir Bengkulu juga telah melakukan budidaya tanaman pertanian. Hasil penelitian menunjukkan kawasan pesisir Bengkulu dapat digunakan untuk budidaya cabe (Bertham et al. 2013) dan kedelai (Monalisa 2016). Pemilihan genotipe tanaman yang tepat dan teknologi organik dan pupuk hayati digunakan dalam budidaya tanaman tersebut. Namun demikian masyarakat pesisir umumnya belum mengenal teknologi demikian.

Sebagian wilayah Kabupaten Bengkulu Tengah berbatasan langsung dengan Samudera Indonesia.Salah satu di antaranya ialah Kecamatan Pondok Kelapa. Desa Pekik Nyaring dan Sidorejo merupakan dua buah desa yang terletak di Kecamatan Pondok Kelapa yang memiliki daratan pesisir lautan. Tanah pesisir, yang dapat diklasifikasikan sebagai Entisol atau Regosol, yang membatasi kedua desa tersebut memiliki karakteristik yang menyebabkan budidaya tanaman tidak dapat dilaksanakan oleh petani yang tidak memiliki ketrampilan teknologi yang tinggi. Kecamatan Pondok Kelapa memiliki jumlah penduduk terbesar dibandingkan kecamatan lainnya.

Petani di kecamatan Pondok Kelapa telah akrab dengan budidaya tanaman pangan (padi dan palawija) dan tanaman hortikultura (sayuran seperti kacang panjang, cabe besar tomat, terung, buncis dan sebagainya). Produksi cabe besar dari kecamatan ini merupakan yang tertinggi dibandingkan dari kecamatan lainnya. Cabai merupakan produk nabati yang bersifat multiguna, karena dapat digunakan sebagai bahan pangan maupun obat-obatan. Produksi cabai seringkali terkendala oleh musim dan serangan penyakit sehingga menyebabkan produksi dan harga jual cabai menjadi fluktuatif, seringkali harga melambung tinggi namun kemudian anjlok drastis sampai titik nadir, oleh karena itu perlu dikembangkanteknologi tepat guna yang dapat dimanfaatkan oleh masyarakat pesisir untuk memproduksi cabai.

Penggunaan pupuk organik dan pupuk hayati diduga dapat memperbaiki adaptabilitas cabai pada tanah pesisir. Pupuk organik memiliki bermacam-macam fungsi, 
misalnya meningkatkan kemampuan tanah mengikat air, sumber hara dan substrat jasad renik tanah, sumber muatan yang menahan pupuk agar tidak mudah tercuci, mendetoksifikasi pestisida dan senyawa logam berat. Selain pupuk organik, fungi mikoriza arbuskula (FMA) yang merupakan salah satu komponen pupuk hayati, telah diketahui perannya dalam meningkatkan adaptabilitas tanaman cabai yang tumbuh pada tanah berkadar garam tinggi (Rueda-Puente et al., 2010). Berdasarkan fakta tersebutdiatas dapat dihipotesiskan bahwa budidaya cabai berkemungkinan besar dapat dilaksanakan di kawasan pesisir jika mendapatkan sentuhan teknologi yang tepat, yaitu penggunaan genotipe unggul, bahan organik, dan pupuk hayati FMA. Teknologi dan budidaya cabai demikian pada dasarnya dapat ditularkan kepada masyarakat pesisir agar dapat memanfaatkan lahan di sekitar pemukimannya sekaligus memperbaiki taraf hidupnya.

Adapun tujuan program pengabdian kepada masyarakat yang dibiyai oleh Direktorat IbM adalah: mengembangkan masyarakat kelompok tani kawasan pesisir yang mandiri secara ekonomi dan meningkatkan ketrampilan pembuatan pupuk hayati yang spesifik di kawasan pesisir.

\section{METODE PENGABDIAN}

\section{Permasalahan Petani}

Wawancara dengan petani sasaran dilaksanakan untuk mengetahui kendala yang dihadai para petani dalam melaksanakan budidaya cabe di lahan pesisir laut.Setelah dilakukan wawancara dengan Kelompok Tani Setia Rukun Desa Pekik Nyaring dan dan Muda Mandiri Desa Beringin Raya dapat diketahui permasalahan yang dihadapi oleh mitra diantaranya adalah (1) belum dikuasainya teknologi organik khususnya dalam penyediaan pupuk organik, (2) belum dikuasainya pengetahuan memproduksi inokulan pupuk hayati, khususnya fungi mikoriza arbuskula, dan (3) belum dikuasainya pengetahui budidaya cabai di tanah pesisir dengan memanfaatkan pupuk organik dan pupuk hayati.

\section{Bentuk kegiatan}

Kegiatan IbM ini dirancang terdiri atas 3 kegiatan yang saling berkesinambungan yang terdiri atas pendidikan dan penyuluhan, pelatihan dan pembuatan demplot percobaan di lapang.

\section{Pendidikan dan Penyuluhan}

Kegiatan ini bertujuan untuk menambah wawasan dan memperkaya cara berfikir kelompok tani serta anggotanya tentang masalah utama dan target solusi yang ditawarkan. Kegiatan yang akan dilaksanakan meliputi (1) pengenalan sifat dan ciri-ciri kawasan pesisir dan potensinya untuk budidaya cabai organik, dan (2) pengenalan tentang potensi pupuk hayati (FMA) dan bahan organik untuk membantu adaptabilitas tanaman agar 
mampu tumbuh pada tanah yang berkadar garam tinggi, meningkatkan serapan hara, meningkatkan daya tahan tanaman terhadap hama penyakit, dan sebagainya.

\section{Pelatihan}

Tim IbM akan memberikan pelatihan budidaya cabai organik dan produksi inokulan fungi mikoriza arbuskula kepada masing-masing 5 (lima) orang wakil kelompok tani dari Desa Pekik Nyaring dan Desa Beringin Raya. Kesepuluh orang tersebut kemudian akan mensosialisasikannya kepada anggota kelompok tani lainnya. Pelatihan diadakan selama 6 (enam) hari dengan materi (1) pengenalan dan produksi inokulan FMA, (2) pengenalan dan produksi pupuk organik, dan (3) budidaya cabai organik di tanah pesisir. Peserta pelatihan secara bersama-sama difasilitasi sebuah rumah kawat/bambu sederhana di Desa Pekik Nyaring dan Sidorejo dilengkapi dengan rak-rak kayu untuk menempatkan kultur FMA. Kultur FMA dimasukkan ke dalam wadah plastik berisi media pasir atau zeolit dan FMA dari lahan pesisir. Tanaman inang yang digunakan ialah Prueraria phaseoloides var javanica, padi, atau sorghum.Lima orang dari setiap desa kemudian melatih 15 orang warga desanya. Pelatihan tersebut dengan didampingi oleh Tim IbM. Pelatihan produksi inokulan FMA dan pupuk organik ini akan memakan waktu sekitar 3 (tiga) bulan.

\section{Demplot Percobaan}

Setelah petani menguasai teknologi produksi inokulan FMA dan pupuk organik kemudian petani akan dilatih mengaplikasikannya di lapangan yaitu pada pertanaman cabai. Pada setiap desa akan disewakan sebidang tanah seluas kurang lebih $300 \mathrm{~m}^{2}$ untuk ditanami cabai. Benih cabai dan pupuk dasar akan difasilitasi dari kegiatan IbM. Demoplot disusun secara Split-split plot dengan Rancangan Acak Kelompok Lengkap dua faktor. Petak utama adalah lokasi atau desa, anak petak adalah genotipe cabai yang telah teruji mampu tumbuh pada tanah pesisir yaitu I2912 dan 35C2, anak-anak petak adalah pemberian pupuk NPK, pupuk kandang sapi (pukan), NPK + pupuk kandang sapi (NPK+pukan), FMA + pupuk kandang sapi (miko-pukan). Faktor kedua ialah dua jenis cabai yang telah teruji mampu tumbuh pada tanah pesisir yaitu I2912 dan 35C2. Kedelapan kombinasi perlakuan tersebut diulang tiga kali sehingga terdapat 24 satuan percontohan. Setiap percobaan berukuran $2 \mathrm{~m}$ x $2 \mathrm{~m}$, jarak tanam $40 \mathrm{~cm}$ x $40 \mathrm{~cm}$, dan jarak antar petak $50 \mathrm{~cm}$. Keberhasilan setiap petak percobaan dinilai dari kemampuan tanaman untuk tumbuh baik dan menghasilkan buah cabai yang sehat. Panen dilakukan jika 50\% tanaman dalam satu petak telah berbuah dengan $75 \%$ buah berwarna merah.

\section{HASIL DAN PEMBAHASAN}

Kegiatan diawali dengan survey untuk menentukan lokasi kegiatan pengabdian kepada masyarakat. Survey lokasi dilaksanakan pada bulan Februari 2016 dan diikuti dengan penyidikan tanah untuk melihat kesesuaiannya untuk pelaksanaan kegiatan. Tanah 
yang digunakan adalah tanah pesisir laut yang memiliki karakteristik tekstur pasiran, miskin bahan organik, dan unsur hara khususnya nitrogen. Selanjutnya pada bulan April 2016 dilakukan penyiapan dan pembuatan rumah plastik untuk produksi pupuk hayati fungi mikoriza arbuskula di desa sasaran (Gambar 1). Kegiatan berikutnya adalah sosialisasi dan pelatihan kepada kelompok petani sasaran yang dilaksanakan pada tanggal 13-14 Maret 2016. Secara berturut-turut kepada petani sasaran diberikan pemahaman mengenai potensi lahan pesisir untuk budidaya tanaman pertanian danmanfaat dan produksi inokulan fungi mikoriza arbuskula. Setelah kegiatan tersebut kemudian kepada petani diberikan pelatihan pembuatan inokulan mikoriza dan biokompos (Gambar 2).
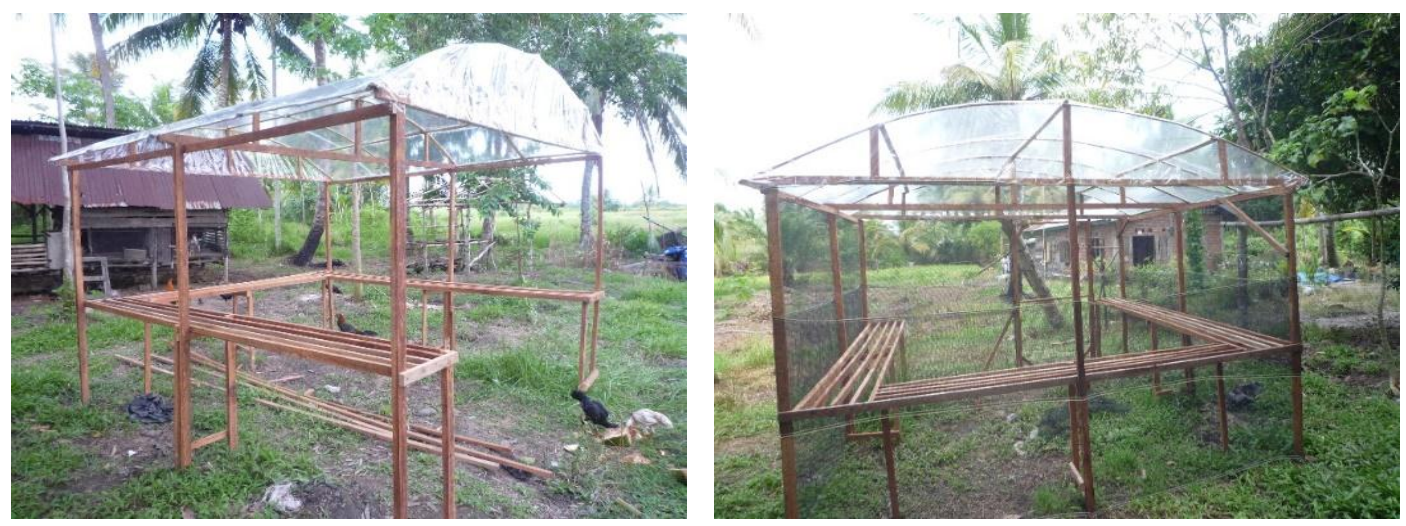

Gambar 1. Rumah plastik untuk produksi fungi mikoriza arbuskula
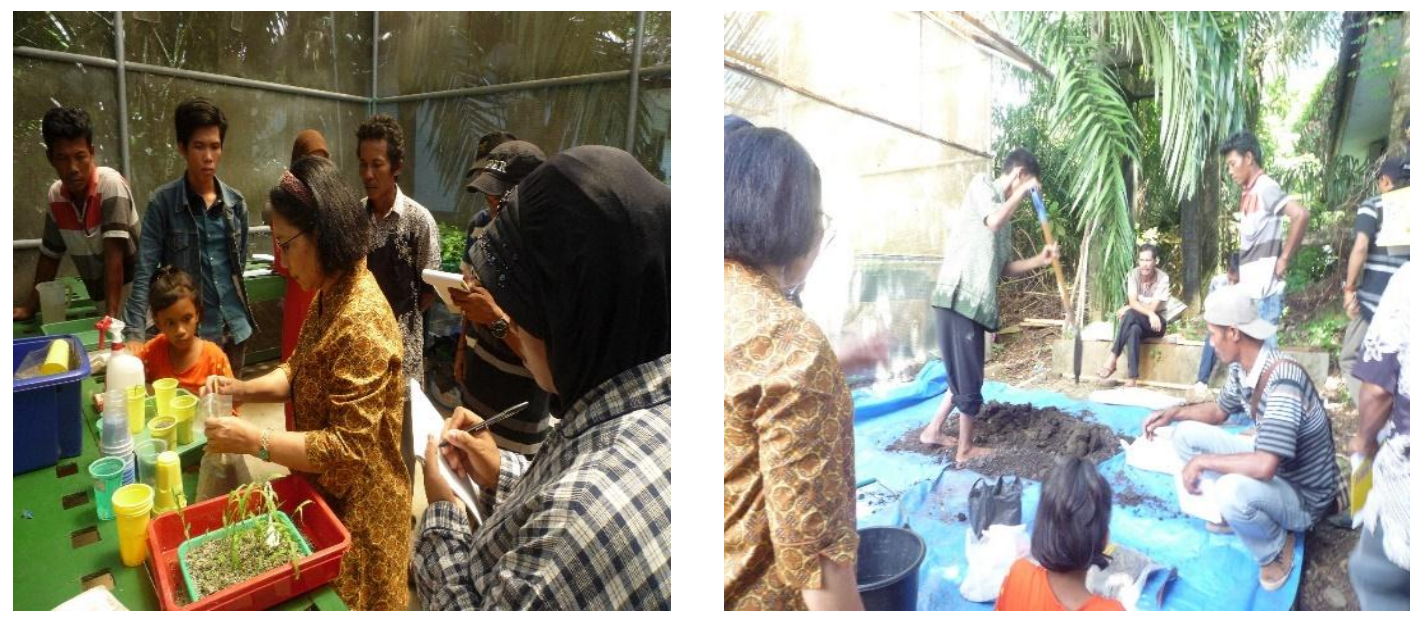

Gambar 2. Pelatihan pembuatan inokulan fungi mikoriza (kiri) dan biokompos (kanan)

Pada tahap berikutnya petani didampingi melakukan pembuatan pupuk hayati di lokasinya masing-masing. Hasilnya kemudian digunakan dalam demoplot penanaman kedelai di kawasan pesisir.Lahan yang akan ditanami dibersihkan dari gulma, sisa-sisa akar, dan kotoran lainnya. Kemudian diolah dengan menggunakan cangkul dan garu. 
Pengolahan tanah dilaksanakan pada tanggal 15 - 21 April 2016. Petak percobaan dibuat dengan ukuran $2 \mathrm{~m}$ x $2 \mathrm{~m}$, jarak antar petak selebar $50 \mathrm{~cm}$, dan jarak tanam $40 \mathrm{~cm}$ x $40 \mathrm{~cm}$. Demoplot dibuat di Desa Beringin Raya dan Pekik Nyaring. Cabai yang diuji ada dua genotipe yaitu 35C2 dan 12912, pupuk yang diberikan adalah NPK, pupuk kandang sapi, campuran inokulan fungi mikoriza arbuskula dengan pupuk kandang, dan campuran pupuk NPK dan pupuk kandang sapi. Pemberian pupuk dasar diberikan pada tanggal 23 April 2016 sedangkan penanaman dilaksanakan pada tanggal 24 April. Kegiatan selanjutnya adalah pemeliharaan tanaman yang meliputi penyiraman, penyiangan, dan pemberantasan hama dan penyakit.

Pada tahap awal terjadi kegagalan pertumbuhan, daun mengalami khorosis kanan) yang mengindikasikan terjadinya kekurangan hara dan keracunan $\mathrm{Na}$ atau $\mathrm{Cl}$. Selain itu, faktor pemeliharaan tanaman dirasakan kurang intensif sehingga proses pencucian garam berlangsung kurang sempurna. Karena buruknya pertumbuhan maka penanaman cabai diulangi kembali.

Setelah menelaah faktor-faktor yang diduga menjadi penyebab buruknya pertumbuhan tanaman cabai maka kemudian dirancang penanaman kembali. Hasilnya menunjukkan tanaman cabai berhasil tumbuh dengan baik sampai berakhirnya pertumbuhan (Gambar 3). Hal tersebut menunjukkan bahwa sangat dimungkinkan melakukan budidaya cabai di lahan pesisir. Data hasil tanaman cabai kemudian dianalisis dengan Uji F menggunakan model Split split-plot dengan rancangan dasar Rancangan Acak Kelompok Lengkap, setiap perlakuan diulang 3 kali. Hasilnya menunjukkan adanya pengaruh Lokasi atau Desa (Desa Beringin Raya dan Desa Pekik Nyaring) dan Pupuk sedangkan Genotipe cabai berpengaruh tidak nyata terhadap jumlah cabai, bobot buah cabai, dan kolonisasi mikoriza (Tabel 1).
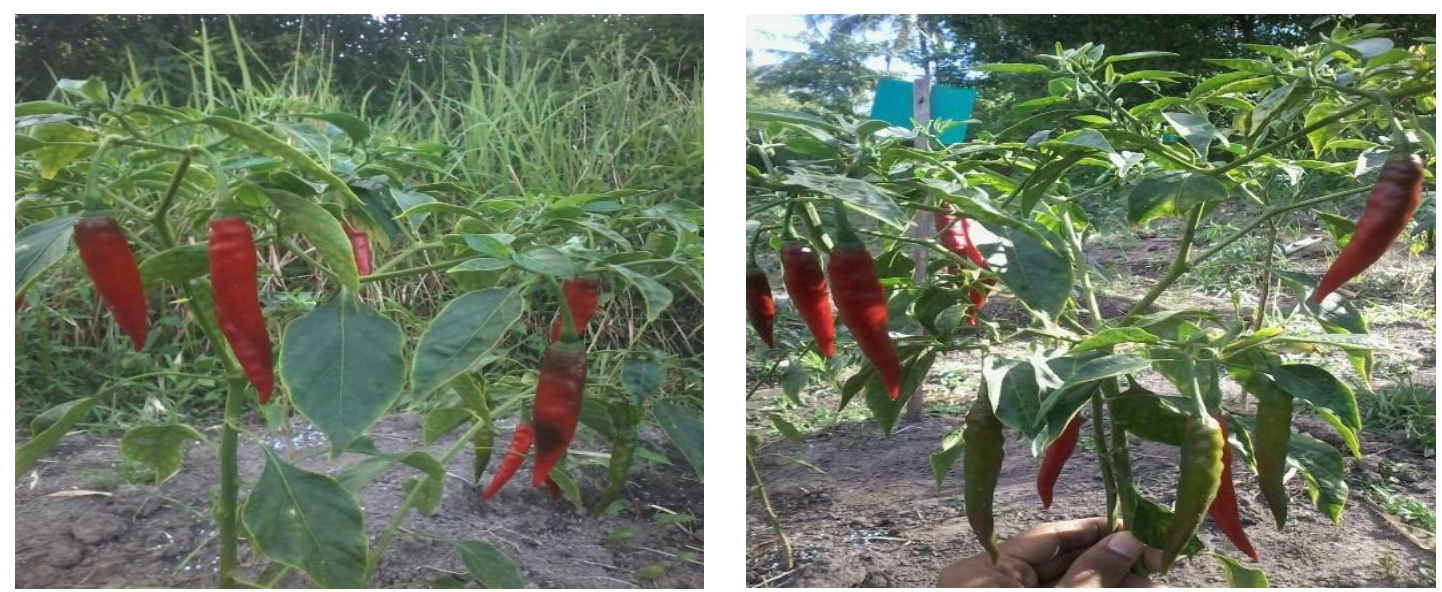

Gambar 7. Pertumbuhan dan hasil cabai di lokasi 
Tabel 1. Pengaruh Lokasi dan Pupuk terhadap Jumlah Buah, Bobot Buah, dan Kolonisasi Mikoriza

\begin{tabular}{|c|c|c|c|c|c|c|c|c|}
\hline \multirow{2}{*}{$\begin{array}{r}\text { Faktor } \\
\text { Lokasi/Desa }\end{array}$} & \multicolumn{2}{|c|}{$\begin{array}{c}\text { Jumlah } \\
\text { buah }\end{array}$} & \multicolumn{2}{|c|}{$\begin{array}{l}\text { Bobot buah } \\
\text { per tanaman }\end{array}$} & \multicolumn{2}{|c|}{$\begin{array}{l}\text { Bobot buah } \\
\text { per Ha (ton) }\end{array}$} & \multicolumn{2}{|c|}{$\begin{array}{c}\text { Kolonisasi } \\
\text { mikoriza }(\%)\end{array}$} \\
\hline & & & & & & & & \\
\hline Beringin Raya & 27 & $\mathrm{a}$ & 43.38 & $\mathrm{a}$ & 2.71 & $\mathrm{a}$ & 76 & $\mathrm{a}$ \\
\hline Pekik Nyaring & 13 & $\mathrm{~b}$ & 17.49 & $\mathrm{~b}$ & 1.09 & $\mathrm{~b}$ & 68 & $\mathrm{a}$ \\
\hline \multicolumn{9}{|l|}{ Genotipe } \\
\hline $35 \mathrm{C} 2$ & 21 & $\mathrm{a}$ & 31.53 & $\mathrm{a}$ & 1.97 & $\mathrm{a}$ & 74 & $\mathrm{a}$ \\
\hline $\mathrm{I} 2912$ & 20 & $\mathrm{a}$ & 29.35 & $\mathrm{a}$ & 1.83 & $\mathrm{a}$ & 71 & $\mathrm{a}$ \\
\hline \multicolumn{9}{|l|}{ Pupuk } \\
\hline NPK & 16 & $\mathrm{~b}$ & 24.89 & $\mathrm{~b}$ & 1.56 & $\mathrm{~b}$ & 63 & $\mathrm{c}$ \\
\hline Pupuk kandang sapi & 19 & $\mathrm{~b}$ & 28.78 & $\mathrm{~b}$ & 1.80 & $\mathrm{~b}$ & 73 & $\mathrm{~b}$ \\
\hline $\mathrm{NPK}+$ pukan & 20 & $\mathrm{~b}$ & 29.73 & $\mathrm{~b}$ & 1.86 & $\mathrm{~b}$ & 62.5 & $\mathrm{c}$ \\
\hline Mikoriza + pukan & 26 & $\mathrm{a}$ & 38.35 & $\mathrm{a}$ & 2.40 & $\mathrm{a}$ & 90 & $\mathrm{a}$ \\
\hline Koef. Keragaman (\%) & \multicolumn{2}{|c|}{4} & \multicolumn{2}{|c|}{6} & \multicolumn{2}{|c|}{6} & \multicolumn{2}{|c|}{14} \\
\hline
\end{tabular}

Keterangan: Rerata sekolom diikuti huruf sama menunjukkan berbeda tidak nyata menurut Uji Beda Nyata Terkecil (LSD) pada taraf nyata 5\%.

Kolonisasi fungi mikoriza arbuskula (FMA) pada akar tanaman cabe yang tumbuh di kedua lokasi demoplot terlihat sama persentasenya (Tabel 1). Fenomena demikian perlu ditelaah dengan hati-hati. Kesamaan aras kolonisasi pada fase generatif atau tanaman umur 10 minggu setelah tanaman dapat terjadi karena kolonisasi FMA telah mencapai aras yang maksimal untuk masing-masing genotipe cabe di kedua lokasi. Barangkali akan berbeda hasilnya jika diamati kedinian dan perkembangan kolonisasi dari waktu ke waktu pada setiap genotipe cabe di setiap lokasi demoplot. Pada kondisi demikian akan terlihat genotipe yang paling dini dikolonisasi FMA dan perkembangan kolonisasinya pada umur selanjutnya. Oleh karena itu, secara umum dapat dikatakan bahwa tanah di kedua lokasi memiliki potensi propagul FMA yang kurang lebih sama.

Jumlah dan bobot buah per tanaman nyata lebih tinggi, sekitar dua kali lipatnya, di Desa Beringin Raya dibandingkan dengan di Pekik Nyaring. Tanah di Desa Pekik Nyaring kondisinya kalah baik dibandingkan dengan yang di Desa Beringin Raya, tanahnya keras dan di dalamnya banyak perakaran.

Jumlah dan bobot buah per tanaman tertinggi dihasilkan oleh perlakuan pupuk kandang sapi yang dicampur dengan inokulan fungi mikoriza. Bahan organik dapat berfungsi ganda yaitu sebagai penyedia unsur hara dan pembenah tanah. Hara dihasilkan oleh hasil dekomposisi bahan organik yang melepaskan ion-ion yang dibutuhkan tanaman, khususnya N, P, K dan sebagainya. Adanya bahan organik juga dapat meningkatkan kadar air tanah sehingga pertumbuhan tanaman dapat terjaga dengan baik. Secara teoritis bahan organik mampu mengingkat air sampai 10 kali dari bobot keringnya. Selain itu, bahan organik juga dapat meningkatkan kapasitas tukar kation sehingga hara hasil dekomposisi dapat terikat oleh partikel tanah dan tidak mudah hilang tercuci. Keuntungan lain dari 
adanya bahan organik adalah tersedianya substrat karbon untuk jasad renik dalam tanah. Ketersediaan substrat karbon dapat meningkatkan populasi dan aktivitas jasad renik dalam tanah sehingga peran tanah faktor pertumbuhan tanaman dapat menjadi semakin optimal.

Fungi mikoriza arbuskula (FMA) merupakan fungi yang berfungsi ganda sehingga dapat melindungi tanaman dari cekaman biotik dan abiotik. Salah satu peran penting FMA adalah melindungi tanaman dari cekaman kegaraman atau salinitas tanah.Tanaman bermikoriza yang tumbuh pada tanah bergaram umumnya tumbuh lebih baik dibandingkan dengan tanaman tidak bermikoriza. Selain itu, tanamannya lebih sehat atau lebih tahan terhadap serangan hama dan penyakit, pembuahannya lebih baik. Keuntungan lain adalah FMA sebagai pupuk hayati cukup diberikan sekali ke dalam tanah tidak perlu dilakukan berulang kali seperti halnya pupuk buatan. Selain itu, inokulan FMA dapat diperbanyak sendiri oleh petani atau masyarakat pada umumnya menggunakan bahan yang murah dan aman bagi manusia dan lingkungan. Kegiatan pelatihan dan pendampingan kelompok tani dalam pembuatan inokulan FMA dengan demikian menjadi penting artinya.

Kegiatan sosialisasi, pelatihan, dan pendampingan pembuatan inokulan FMA dapat dikembangkan pada masyarakat di kawasan pesisir selain di desa sasaran. Selain inokulan FMA, petani juga dapat diberikan pengetahuan dan keterampilan dalam menyiapkan, memformulasikan, dan menggunakan pupuk hayati lainnya seperti rhizobia dan pelarut fosfat. Jika, petani kawasan pesisir menguasai teknologi inokulan pupuk hayati maka diharapkan mereka dapat terlepas dari ketergantungannya dari usaha menangkap ikan pada saat tidak mungkin melakukan penangkan ikan. Para keluarga nelayan dengan demikian diharapkan dapat meningkatkan taraf hidupnya melalui usaha lain yaitu di bidang pertanian kawasan pesisir. Para keluarga nelayan dapat melakukan budidaya beraneka jenis tanaman di kawasan pesisir menggunakan pupuk hayati yang murah, mudah diperoleh, dan aman bagi manusia dan lingkungam.

Pertumbuhan dan produksi cabai yang dikembangkan untuk tanah mineral masam pasti akan mengalami perubahan jika ditumbuhkan pada tanah pesisir. Cabai memerlukan struktur remah kaya bahan organik dan perlu air yang cukup, sedangkan tanah pesisir pada umumnya memiliki kadar garam terlarut atau nisbah $\mathrm{Na}^{+} / \mathrm{K}^{+}$yang tinggi dan kadar ion $\mathrm{Na}^{+}$ dan $\mathrm{Cl}^{-}$yang tinggi (Yamaguchi \& Blumwald, 2005) sehingga menurunkan efisiensi fotosintesis yang disebabkan oleh (a) penutupan stomata, (b) penurunan kadar protein (Sibole et al. 1998) namun hal tersebut juga disebabkan lamanya tanaman menderita cekaman kegaraman (Misrha et al., 1997) dan spesies tanaman.

Penggunaan bahan organik, misalnya dalam bentuk kompos, dan pupuk hayati, misalnya dalam bentuk fungi mikoriza arbuskula, dapat memperbaiki adaptabilitas cabai pada tanah pesisir. Bahan organik memiliki beraneka fungsi, misalnya meningkatkan kemampuan tanah mengikat air, sumber hara dan substrat jasad renik tanah, sumber muatan yang menahan pupuk agar tidak mudah tercuci, mendetoksifikasi pestisida dan senyawa logam berat dan lain sebagainya. Pengaruh positif kompos untuk meningkatkan pertumbuhan tanaman, misalnya jagung manis (Handajaningsih, 2009) dan cabai (Gustia, 
2009) telah dilaporkan. Berbagai penelitian telah berhasil membuktikan bahwa berbagai bahan organik misalnya limbah rumah tangga, sari limbah, dan gambut bermanfaat untuk membenahi sifat-sifat tanah termasuk untuk tanah berkadar garam tinggi (Diaz et al., 1994, Roldan et al., 1996).

Fungi mikoriza arbuskular (FMA) merupakan fungi yang bersifat obligat, atau harus hidup bersimbiosis dengan inangnya, dan bersimbiosis dengan kurang lebih $90 \%$ tanaman darat (Smith \& Read, 2008). Tanaman yang bersimbiosis dengan FMA mampu tumbuh dan berproduksi lebih baik dibandingkan dengan tanaman yang tidak bermikoriza. Hal tersebut dikarenakan FMA terlibat dalam berbagai proses di dalam tanah misalnya dalam agregasi tanah (Miller \& Jastrow, 2000), perombakan bahan organik, pergerakan hara dan air (Smith \& Read 2008). Fungi mikoriza arbuskula terbukti mampu hidup pada tanah berkadar garam tinggi (Juniper \& Abbott, 1993). Tanaman cabai yang ditumbuhkan di tanah pesisir Bengkulu terbukti dikolonisasi oleh FMA (Bertham et al., 2013).Tanaman bermikoriza ditemukan lebih tahan terhadap serangan patogen (Garmendia et al., 2004) cekaman kekeringan, logam berat, dan salinitas (Brundrett 1991, Turkmen et al., 2005). Kolonisasi FMA dapat meningkatkan pertumbuhan dan serapan hara sekaligus mengurangi potensi penurunan hasil tanaman tomat pada tanah salin (Alkaraki, 2000). Pada banyak kasus telah terbukti bahwa FMA merupakan ameliorator hayati untuk tanah tanah salin (Sing et al., 1997, Kaya et al., 2009). Oleh sebab itu keeratan hubungan antara tanaman dan FMA menjadi penting artinya untuk suatu kondisi pertumbuhan tertentu (Tian et al., 2004). Hasil penelitian menunjukkan tanaman yang bersimbiosis dengan FMA pada tanah berkadar garam tinggi umumnya memiliki kemampuan menyerap hara N, P, dan K (Kaya et al., 2009) oleh karena itu memiliki adaptabilitas yang tinggi (Rueda-Puente et al., 2010).

\section{KESIMPULAN DAN SARAN}

Budidaya cabai dapat dilaksanakan di lahan pesisir dengan memperhatikan masukan organik dan pupuk hayati. Kepada petani dapat dikenalkan dan didampingi metode perbanyakan pupuk hayati dan inokulasinya serta pembuatan biokompos untuk meningkatkan pertumbuhan dan hasil cabai. Potensi fungi mikoriza yang ada perlu dikembangkan menjadi inokulan agar dapat dimanfaatkan oleh petani setempat. Desa Beringin Raya lebih berpotensi untuk budidaya cabai dibandingkan Desa Pekik Nyaring. Perlu diformulasikan teknologi yang lebih baik untuk budidaya cabai di Desa Pekik Nyaring.

\section{UCAPAN TERIMA KASIH}

Ucapan terima kasih disampaikan kepada Direktorat Riset dan Pengabdian MasyarakatDirektorat Jenderal Penguatan Riset dan PengembanganKementerian Riset, Teknologi, dan Pendidikan Tinggiyang telah membiayai kegiatan ini melalui Skim Ipteks 
Bagi Masyarakat sesuai dengan Surat Perjanjian Penugasan Pelaksanaan Program Pengabdian kepada Masyarakat Nomor: 030/SP2H/ LT/DRPM/2016, tanggal 17 Februari 2016.

\section{DAFTAR PUSTAKA}

Al-Karaki G.N., 2000, Growth and mineral acquisition by mycorrhizal tomato grown under salt stress, Mycorrhiza 10:51-54.

Badan Pusat Statistik Kabupaten Bengkulu Tengah, 2012, Kabupaten Bengkulu Tengah Dalam Angka.

Bertham, Y.H., Handajaningsih M., Ganefianti D.W., 2013, Ujicoba Budidaya Cabai Organik di Lahan Pesisir Bengkulu. Prosiding Semirata Bidang Ilmu-Ilmu Pertanian, Fak. Pertanian UNTAN dan BKS PTN Wilayah Barat, 19-20 Maret 2013.

Brundrett, M., 1991, Mycorrhizas in Natural Ecosystem, Adv Ecol Res 21:171-313.

Diaz E., Roldan A., Lax A., Albaladejo J., 1994, Formation of stable aggregates in adegraded soil by amendment of urban refuse and peat. Geoderma, 63:277-299.

Garmendia I., Goicoechea N., Aguireolea J., 2004, Effectiveness of tree Glomus spesies in protecting pepper (Capsicum annum L.) against verticilium wilt, Biol Control, 31:296-305.

Gustia H., 2009, Pemberian bokasi terhadap pertumbuhan dan produksi tanaman cabe var. -99, Akta Agrosia, 12: 106-114.

Handayaningsih M., 2009, Growth and yield of sweet corn grown organically using palm oilsludge at diffrentdoses and composting methods, Akta Agrosia, 12: 99-105.

Juniper S., Abboth L., 1993, Vesicular arbuscular mycorrhizas and soil salinity, Mycorrhiza 4:45-57.

Kaya C., Ashraf M., Sonmez O., Aydemir S., Tuna Al, Cullu M.A., 2009, The influenceofarbuscu-lar mycorrhizal colonization on key growth at high salinity, Sci Hort, 121:1-6.

Miller R.M., Jastrow J.D., 2000, Mycorhizal fungi influence soil structure, HLM 3-18 di dalam Kapulnik Y., Douds Jr. D.D.(ed), Arbuscular mycorrhizas: Physiology and Fungtion, Kluwer Academic publication, The Hague.

Misrha S.K., Subralimanyam D., Singhal G.S., 1997, Interactionshipbetween salt ang light strees on the primary process of photosynthesis, J Plant Physiol, 138:92-96.

Roldan, A., Thornes J.B., 1996, Aggregate stability changes in a semiarid soil after treatmens with different organic amendments, Arid Soil Res Rehab, 10:139-148.

Rueda-Puente E.O., Murillo-Amador B., Castellanos-Cerfantes T., Garcia-Hernandez. J.L., Taarazon-Herera M.A., Medina S.M., Barrera L.E.G., 2007, Effects of plant growth promoting bacteria and mycorrhizae on Capsicum annuumL.var aviculare germination under stressing abiotic conditions, Plant Physiol Biochem, 48:724-730. 
Sibole J.V., Montero E., Cabot C., Poschenrieder C.B., 1998, Role of sodium in the ABAmediated long-term growth respons of bean to salt stress, Physiol Plant, 104: 299305.

Smith S.E., Read D.J., 2008, Mycorrhizal Symbiosis, $3^{\text {rd }}$ ed, Academic Press, San Diego.

Tian C.Y., Feng G., Li X.L., Zhang F.S., 2004, Different effect of arbuscular mycorrhizal fungal isolates from saline soil or non-saline soil on salinity tolerance of plants, Appl Soil Ecol, 26:143-148.

Turkmen O., Demir S., Sensoy S., Dursun A., 2005., Effects of arbuscular mycorrhizal fungus and humic acid on the seedling development and nutrient content of pepper grown from heavy-metal polluted soils, J Biol Sci, 5:568-574.

Yamaguchi T., Blumwald E., 2005, Developping salt-tolerant crop plants: challenges and opportunities, Trends Plant Sci, 10:615-620. 